This item was submitted to Loughborough's Research Repository by the author.

Items in Figshare are protected by copyright, with all rights reserved, unless otherwise indicated.

\title{
Rural population geographies in the changing differentiated countryside?
}

\section{PLEASE CITE THE PUBLISHED VERSION}

https://www.routledge.com/The-Routledge-Companion-to-Rural-Planning-1st-Edition/Scott-GallentGkartzios/p/book/9781138104051

\section{PUBLISHER}

Routledge

VERSION

AM (Accepted Manuscript)

\section{PUBLISHER STATEMENT}

This is an Accepted Manuscript of a book chapter published by Routledge in Routledge Companion to Rural Planning on 17 January 2019, available online: http://www.routledge.com/9781138104051.

\section{LICENCE}

CC BY-NC-ND 4.0

\section{REPOSITORY RECORD}

Smith, Darren, Martin Phillips, Chloe Kinton, and Andreas Culora. 2019. "Rural Population Geographies in the Changing Differentiated Countryside?". figshare. https://hdl.handle.net/2134/33542. 


\title{
Rural population geographies in the changing differentiated countryside?
}

\section{Darren P. Smith, Martin Phillips, Chloe Kinton \& Andreas Culora}

\begin{abstract}
This chapter provides a broad introduction to rural society and the forces of change. Beginning with the concept of the 'differentiated countryside', and drawing on the case of England and Wales in the UK, the chapter examines contemporary shifting social geographies and the challenges arising from this. Through mapping census data, the chapter overviews these changes by focusing on employment, class, age and different family formations.
\end{abstract}

\section{Introduction}

A prominent hallmark of contemporary rural places is the changing demographics and make-up of local populations (Shucksmith and Brown, 2016), with identities and differentials of age and lifecourse, social class, gender, ethnicity, and family formations all being in states of flux and diversification (Smith, 2007; Phillips, 2010; Shortall, 2015). Of course, this is not a new phenomenon, as stressed by Lowe et al. (2003: 32): 'For most of its history the British countryside has been characterised by considerable diversity'.

During the last 50 years, numerous subdisciplinary-defining studies of rural social change (e.g. Pahl, 1965; Newby, 1980; Cloke and Thrift, 1987; Murdoch and Marsden, 1994) have identified how and why rural populations are reshaped, often in profound ways, by shifting political, economic, social and cultural conditions. This body of work has increasingly shown that longstanding, traditional representations of rural social relations, often founded on the powerful (paternalistic) landed gentry and rural working classes (i.e. deferential workers), have faded in many rural contexts, as local agricultural- 
based economies and communities have been restructured under globalisation and new phases of capitalism (Cloke and Goodwin, 1992; Nelson and Nelson, 2010; Woods, 2010).

Although historical rural relations may persist in some contexts (Sutherland, 2012), most have been superseded by very different sets of rural social relations (Woods, 2004). To capture this changing context, a plethora of new terms have been introduced into the rural studies lexicon to describe the incipient strata of new rural populations, such as rural gentrifiers (Phillips, 1993), 'greentrifiers' (Smith and Phillips, 2001), the 'rural squirearchy' (Heley, 2010), and the 'rural precariat' (Kasimis et al., 2015; McKee et al., 2017; Lever and Milbourne, 2017).

Within Britain, population and demographic processes continue to be fuelled by counterurban impulses and predilections within large segments of British society and the enduring lure of the 'rural idyll' (Halfacree, 2014, 2018; Scott et al., 2017), but are forging new and multiple political, socio-economic, and cultural ruralities. Geographical perspectives continue to reveal the unevenness of rural population outcomes (e.g. Milbourne and Kitchen, 2014), and show the differential ways through which rural populations are reconstituted by the cross-cutting factors of demographic processes (birth / ageing / death rates) and different intra, in- and out-migration flows, both subnationally and internationally.

In tandem, key general transformative forces are widely recognised within rural studies scholarship, such as: the global restructuring of rural economies and labour markets (Bosworth and Venhorst, 2017); changing regimes of agricultural and forestry (post-)production and work (Robinson, 2014); increasing pressures on greenbelts and planning for new-build housing and rural living (Ghartzios and Scott, 2010); legislative protection of specific rural environments (Holloway and Hubbard, 2014), and; advances in information technology and media allowing more flexible work practices (Roberts and Townsend, 2016), and changing patterns of commuting from rural places to metropolitan centres (Clark, 2018). 
Such factors are integral to Lowe et al.'s. (2003) framework of the Differentiated Countryside. Evidenced by dedicated case studies of the socalled 'preserved', 'contested' and 'paternalistic' countryside, it is shown 'how economic, social and political networks act to differentiate rural regions and how the 'new' networks of middle-class counterurbanisers interact with more traditional rural socio-economic formations' (p.75). These interactions are viewed as being pivotal to the growing diversity of rural geographies, and, crucially, 'decisively determines the shape of the differentiated countryside' (ibid).

Within the context of the diversifying countryside, the key aim of this chapter is to deepen understandings of the unevenness of rural population geographies in England and Wales. Using UK census data, the focus of the discussion is centred on six dimensions of contemporary rural population change that are prevalent themes within recent scholarship within rural studies. As a precursor, the next section briefly outlines the methods and data.

\section{Methods}

The following sections present analyses of 2001 and 2011 UK census data that was extracted and manipulated for an on-going ESRC-ORA project, investigating processes and forms of international rural gentrification (iRGENT). ${ }^{1}$ Undertaking temporal and spatial comparisons at geographic resolutions that can effectively identify the distinct scale of rural change (Smith et al., 2018) is a key component of this cross-national project, and a widely employed method of comparison is to employ standardised measures or metrics, albeit not the only method (Phillips and Smith, 2018a). This chapter therefore uses Census variables to explore how rural places and populations have changed between 2001 and 2011, making use of highresolution areal comparable units. To analyse change between 2001 and 2011, 2011 OAs $(181,408$ in total) were matched to 2001 OAs $(175,434$ in total). Of the additional 5,974 OAs, we found that 641 had been merged between 2001-2011, and 6,615 had been split. As a result, our analysis 
identified 182,049 comparable areal units based around OAs. We then used the Rural-Urban Classification (RUC), established by Bibby and Brindley (2013), to identify categories of rural areas (Village; Village in a Sparse Setting; Hamlets and Isolated Dwellings, and; Hamlets and Isolated Dwellings in a Sparse Setting) at the level of Output Areas (OAs). In this chapter we have excluded the RUC rural categories of 'Town and Fringe', and 'Town and Fringe in a Sparse Setting' from our analysis, due to the semi-rural/urban character of many of these locations. This resulted in 17,666 rural units of analysis, of which $54.8 \%$ were Village $(9,992)$; $5.9 \%$ were Village in a Sparse Setting (1,045); 34.2\% were Hamlets and Isolated Dwellings $(6,035)$, and $5.1 \%$ were Hamlets and Isolated Dwellings in a Sparse Setting (894). We focus on these rural areas in this chapter, although we map urban and town and fringe areas within the following Figures (shaded in grey).

Of course, the spatial intensity of rurality varies at a regional level in England and Wales, and this needs to be borne in mind when investigating concentrations of sub-populations. As a percentage of the total rural OAs, most are within the South West (18.5\%), South East (16.9\%), East of England (16.4\%), and, to a lesser extent, East Midlands (10.7\%), Wales (9.6\%) West Midlands (9.6\%), Yorkshire and Humber (8.0\%), and North West (7.3\%). Fewest rural OAs at a regional level are evident within the North East (2.9\%) and, not surprisingly, London (0.2\%).

In the following sections we present spatial analyses of key populationrelated variables, highlighting the relatively high (shaded in red) and low (shaded in blue) extremes within the decile range: very high (90th decile), high (80 $80^{\text {th }}$ decile), low (20th decile) and very low (10th decile) for the mapping of the 2011 census data. We term deciles $\left(30^{\text {th }}-70^{\text {th }}\right)$ between these extremes as 'middling rural' (shaded in olive green) (see Figures 1-9). Our decile calculations are based on rural OAs only, as the inclusion of urban OAs would skew the data. We also undertook analyses of percentage changes between 2001 and 2011, with a focus on very high change (90th decile) and very low change (10th decile). Finally, we also present analyses for the ten regions of 
England and Wales by category of rural area for the $90^{\text {th }}$ decile (see Tables 16) of variables.

\section{Processes of rural population change: some key dimensions}

Dominant representations of rural population change often hinge on the replacement of populations geared towards agricultural (or forestry) production by affluent middle-class households, often perceived to be commuting to nearby metropolitan centres for employment (Smith and Phillips, 2001; Phillips, 2005). Of course, this over-simplistic binary reading of rural population change is readily disrupted when the diversity of rural geographies is woven into analyses (see Stockdale, 2016), not least by the gamut of different physical (and perceptual) distances between rural and urban places, and associated meanings of proximity, distance, attachment and separation between the rural and urban. Also of significance are social differentiations, with work highlighting, for instance, variability in the location of groups within and beyond the middle class (e.g. Hoggart 1997, 2007; Phillips 2005), as well as the presence of populations established through lines of difference such as age, gender, household structure, nd sexuality (e.g. Lowe and Speakman 2001; Philip et al. 2013; Phillips, 1998; Smith and Holt, 2005; Stockdale, 2014). In the following sections we will explore some of these spatial and social lines of differentiation drawing on comparative analyses of the 2001 and 2011 Censuses.

\subsection{Agricultural workers}

As a starting point to explore the unevenness of rural population changes, Figure 1 shows the marked distribution of 'agricultural workers' (NS-SEC 4.8.2 and 4.9.2) in 2011 across England and Wales. It can be seen that OAs in the $90^{\text {th }}$ decile (8.6\%-32.8\%) are highly concentrated in North and Mid Wales (excluding Anglesey), Pembrokeshire, East Cornwall and Devon, North Pennines and Northumberland, Cumbria and Lake District, Yorkshire Dales and North York Moors, and, to a slightly less concentrated extent, the Peak District. As shown in Table 1 these areas have proportions of OAs classified as sparse. These are the sparsely-populated upland areas of England and Wales, where there are distinct pastoral agricultural economies and might be 
viewed as areas of wilderness (see Smith et al., 2018). At the same time, agricultural workers as a percentage of total usual residents is generally not lowered in these areas by the presence of other occupational traits, given it is difficult in these more remote rural locations to commute to nearly metropolitan centres, when compared to the occupational profiles of residents in rural locations on the fringes of metropolitan centres. 


\section{Figure 1: Agricultural rural workers (2011 UK census)}

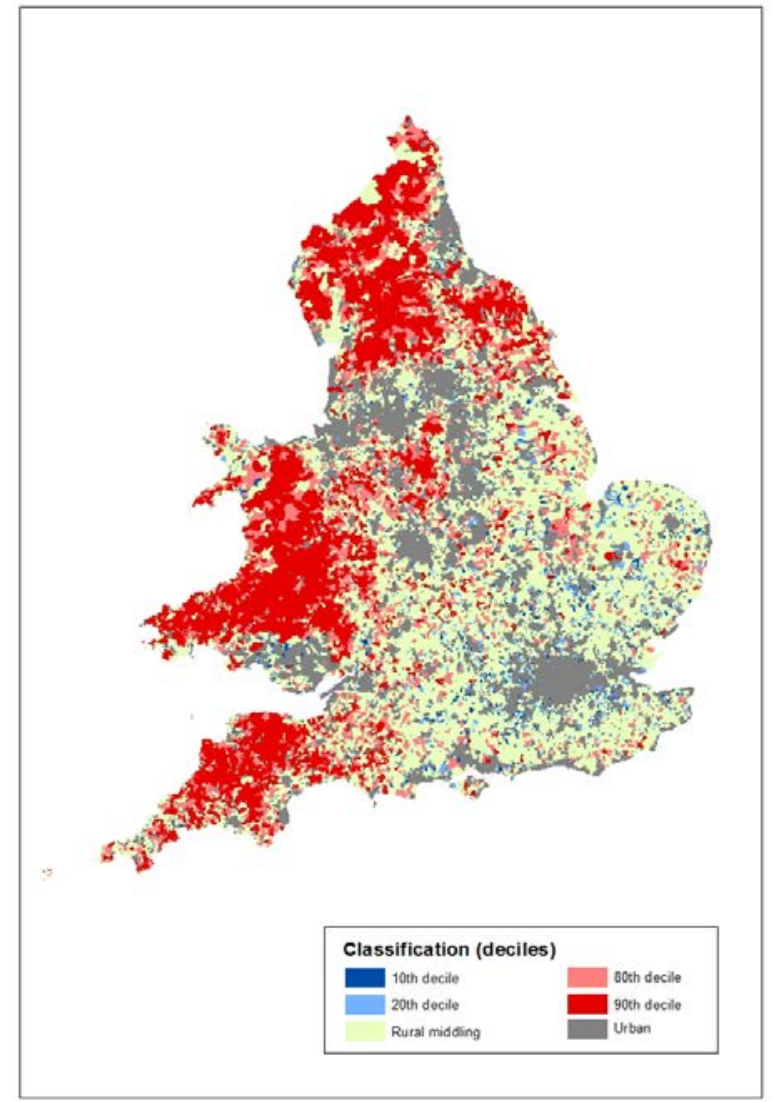

Indeed, it is interesting to note the distribution of OAs in the $10^{\text {th }}$ and $20^{\text {th }}$ agricultural deciles (0\%-0.1\%) within the rural areas relatively close to large metropolitan centres, but beyond the Town and Fringe. Figure 1 may thus serve to demonstrate the differences between the rural economies of sparsely-populated upland areas and those of rural areas in relative proximity to metropolitan centres. In this sense, longstanding notions of the countryside as spaces for agricultural workers appear to be a socio-cultural construct that may be largely applicable only to sparsely-populated upland regions in the English and Welsh context. It is also important to note that there are some areas of upland agricultural land use that have low proportions of agricultural workers, which may point to the presence of relatively high proportions of nonagricultural residents in these areas (e.g. the Trans-Pennine region of Lancashire and Yorkshire).

Table 1 shows a regional breakdown of agricultural workers by RUC category of rural location, and reveals distinct differences between south and central 
England, and areas to the north and west. The highest concentrations of agricultural workers (90th decile) appear in OAs within the South West (25.8\%) and Wales (24.6\%), and, to a lesser extent, North West (13.3\%), West Midlands (12.5\%) and Yorkshire and Humberside (11.8\%). Agricultural workers in the $90^{\text {th }}$ decile are relatively absent in East Midlands (4.5\%), North East (4.9\%), South East (1.1\%) and East of England (0\%). Although the latter may appear be surprising, it may be due to the dominance of large commercial organisations and the implementation of technological advances in agricultural production systems in the East of England (and / or perhaps the use of seasonal labour that does not get fully recorded in the UK census) (Woods, 2008). It is also striking in Table 1 that the relatively high number of OAs in the $90^{\text {th }}$ decile are in the RUC category Hamlets and Isolated Dwellings in a Sparse Setting (597). Indeed, of the total number of OAs defined as Hamlets and Isolated Dwellings in a Sparse Setting (894), it can be seen that the majority $(66.8 \%)$ are in the $90^{\text {th }}$ decile for agricultural workers; emphasising the link between agricultural workers and rural locations in sparse settings. 
Table 1: Regional distribution of agricultural workers by $90^{\text {th }}$ decile (2011 UK census)

\begin{tabular}{|c|c|c|c|c|c|}
\hline & Village & $\begin{array}{l}\text { Village in a } \\
\text { Sparse } \\
\text { Setting }\end{array}$ & $\begin{array}{l}\text { Hamlets and } \\
\text { Isolated } \\
\text { Dwellings }\end{array}$ & $\begin{array}{l}\text { Hamlets and } \\
\text { Isolated } \\
\text { Dwellings in } \\
\text { a Sparse } \\
\text { Setting }\end{array}$ & Total \\
\hline $\begin{array}{l}\text { East } \\
\text { Midlands }\end{array}$ & 18 & 0 & 62 & 0 & $80(4.5 \%)$ \\
\hline $\begin{array}{l}\text { East of } \\
\text { England }\end{array}$ & 1 & 1 & 24 & 0 & $26(0 \%)$ \\
\hline London & 0 & 0 & 0 & 0 & $0(0 \%)$ \\
\hline North East & 6 & 5 & 33 & 43 & $87(4.9 \%)$ \\
\hline North West & 19 & 26 & 121 & 68 & 234 (13.3\%) \\
\hline South East & 2 & & 18 & & $20(1.1 \%)$ \\
\hline South West & 29 & 19 & 284 & 123 & 455 (25.8\%) \\
\hline Wales & 14 & 71 & 87 & 263 & 435 (24.6\%) \\
\hline $\begin{array}{l}\text { West } \\
\text { Midlands }\end{array}$ & 18 & 4 & 147 & 52 & $221(12.5 \%)$ \\
\hline $\begin{array}{l}\text { Yorkshire } \\
\text { and The } \\
\text { Humber }\end{array}$ & 28 & 14 & 118 & 48 & $208(11.8 \%)$ \\
\hline Total & 135 & 140 & 894 & 597 & 1,766 \\
\hline
\end{tabular}

\subsection{Non-agricultural petite-bourgeoisie}

The 2011 census data allows the identification of a non-agricultural petitebourgeoisie (NS-SEC 4.8.2 and 4.9.2) social class (i.e. self-employed workers such as artists, craft workers, Bed and Breakfast and retail owners catering for local tourism). Interestingly, when compared to Figure 1, Figure 2 reveals that OAs in the $90^{\text {th }}$ decile (19.4\%-41.3\%) point to some overlaps between the concentrations of agricultural- and petite-bourgeoisie workers in North Devon (Exmoor), Pembrokeshire, North (Snowdonia), Lake District and Cumbria, and North Yorkshire Moors. The upland agricultural economies and landscapes that are conserved and preserved by the National Park Authorities in these areas clearly seem to foster distinctive local rural tourism economies, which may account for the presence of non-agricultural petite-bourgeoisie 
workers/populations. Moreover, Figure 2 also expresses the relative concentration of OAs in the $90^{\text {th }}$ decile within coastal North / South Cornwall, North Devon, South Devon AONB, Dartmoor, Dorset AONB and Dorset, Cotswolds, Isle of Wight, South Downs, M11 corridor, coastal Norfolk, Southwold coastal area of Suffolk, Shropshire, and, some parts of Lincolnshire. It is possible that these latter places may point to the effects of the restructuring of some local rural economies from agriculture/fishing to more tourism-dependent economies. This may also be connected to the unfolding of processes of rural gentrification, which is discussed below.

Figure 2: Non-agricultural rural workers (2011 UK census)

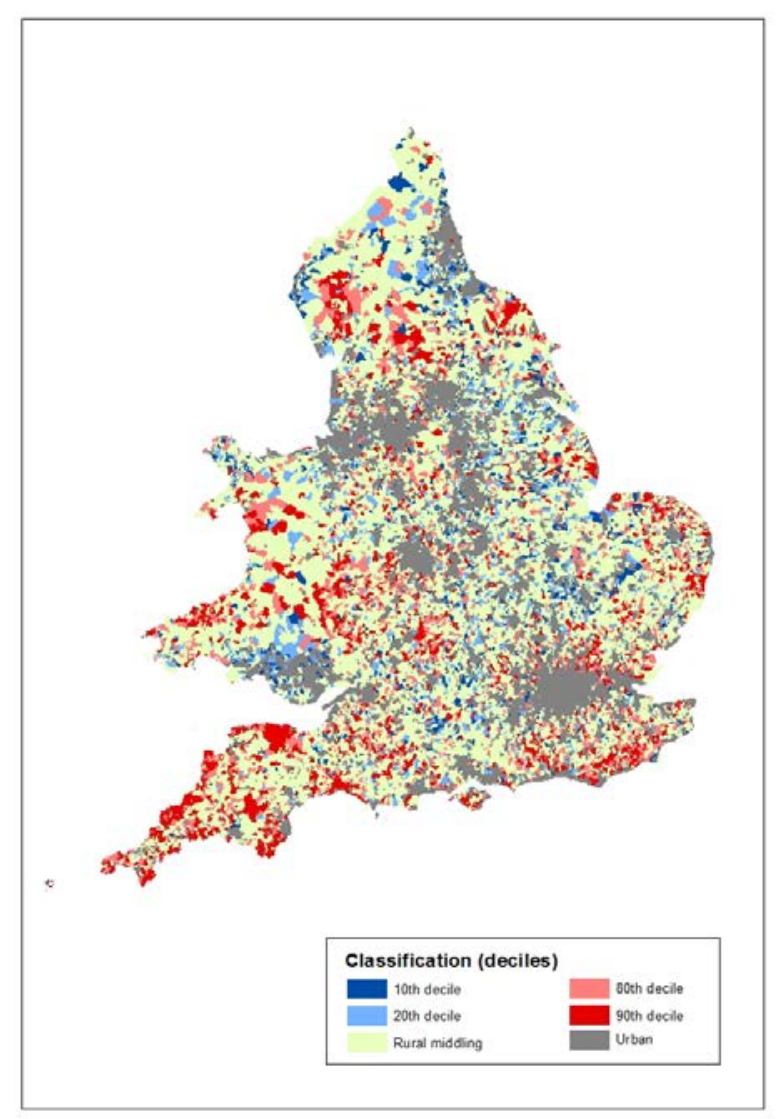


Table 2: Regional distribution of petite-bourgeoisie non-agricultural workers by $90^{\text {th }}$ decile (2011 UK census)

\begin{tabular}{|c|c|c|c|c|c|}
\hline & Village & $\begin{array}{l}\text { Village in a } \\
\text { Sparse } \\
\text { Setting }\end{array}$ & $\begin{array}{l}\text { Hamlets and } \\
\text { Isolated } \\
\text { Dwellings }\end{array}$ & $\begin{array}{l}\text { Hamlets and } \\
\text { Isolated } \\
\text { Dwellings in } \\
\text { a Sparse } \\
\text { Setting }\end{array}$ & Total \\
\hline $\begin{array}{l}\text { East } \\
\text { Midlands }\end{array}$ & 41 & 8 & 45 & 4 & 98 (5.5\%) \\
\hline $\begin{array}{l}\text { East of } \\
\text { England }\end{array}$ & 111 & 16 & 130 & 7 & 264 (14.9\%) \\
\hline London & 3 & & & & $3(0.2 \%)$ \\
\hline North East & 2 & 3 & 3 & 2 & $10(0.6 \%)$ \\
\hline North West & 17 & 20 & 54 & 14 & $105(5.9 \%)$ \\
\hline South East & 140 & & 169 & & $309(17.5 \%)$ \\
\hline South West & 199 & 60 & 233 & 66 & $558(31.6 \%)$ \\
\hline Wales & 7 & 52 & 12 & 62 & $133(7.5 \%)$ \\
\hline $\begin{array}{l}\text { West } \\
\text { Midlands }\end{array}$ & 37 & 5 & 101 & 24 & 167 (9.5\%) \\
\hline $\begin{array}{l}\text { Yorkshire } \\
\text { and The } \\
\text { Humber }\end{array}$ & 32 & 27 & 42 & 18 & $119(6.7 \%)$ \\
\hline Total & 589 & 191 & 789 & 197 & 1766 \\
\hline
\end{tabular}

Table 2 shows that the regional pattern of petite-bourgeoisie non-agricultural workers by $90^{\text {th }}$ decile tends to be most concentrated in OAs within the South West (31.6\%), South East (17.5\%) and East of England (14.9\%). In these regions petite-bourgeoisie non-agricultural workers tend to be clustered along the rural coastline, and, hence, again appears closely tied to the prevalence of rural coastal tourism industries, and perhaps this is linked to the growing rise of a rural creative class (Bell and Jayne, 2010; Anderson et al., 2016).

\subsection{Middle class individuals}

Figure 3 presents the distribution of middle class individuals, calculated based on aggregations of NS-SEC 1, 2 and 4. Particularly notable are relatively high concentrations of OAs in the $90^{\text {th }}$ decile (70.4\%-84.8\%) across the home counties, followed by South Wales, South Devon, South of Manchester, North 
Lancashire and across to Cumbria, and in some parts of Northumberland. It is interesting to note that within this specific set of rural geographies there is a prevalence of Areas of Outstanding Natural Beauty (AONB), such as: Surrey Hills, High Weald, Chilterns, Cotswolds, Shropshire, Quantock Hills/Blackdown Hills, Mendips, Malvern Hills, Nidderdale, Howardian Hills AONBs There are also some concentrations within the National Park areas of: South Downs, Brecon Beacons, Dartmoor, (High) Peak District, Yorkshire Dales, North York Moors, Lake District, and Northumberland. What this may point to is the distribution of the rural middle class populations in highly prized rural locations, which are protected by dedicated state legislation, regulations and management, and where there is available and suitable rural housing stock to gentrify in conspicuous total numbers. Thus, the general lower availability of housing stock in Exmoor and Snowdonia may be a significant factor in the seemingly lower intensity of middle class populations in these National Park areas, as represented by our mapping. What this may emphasise are the differential ways that rural gentrification processes shape National Park areas in the UK, given the inherent diversity of local labour and housing markets in National Park areas. 


\section{Figure 3: Middle class rural populations (2011 UK census)}

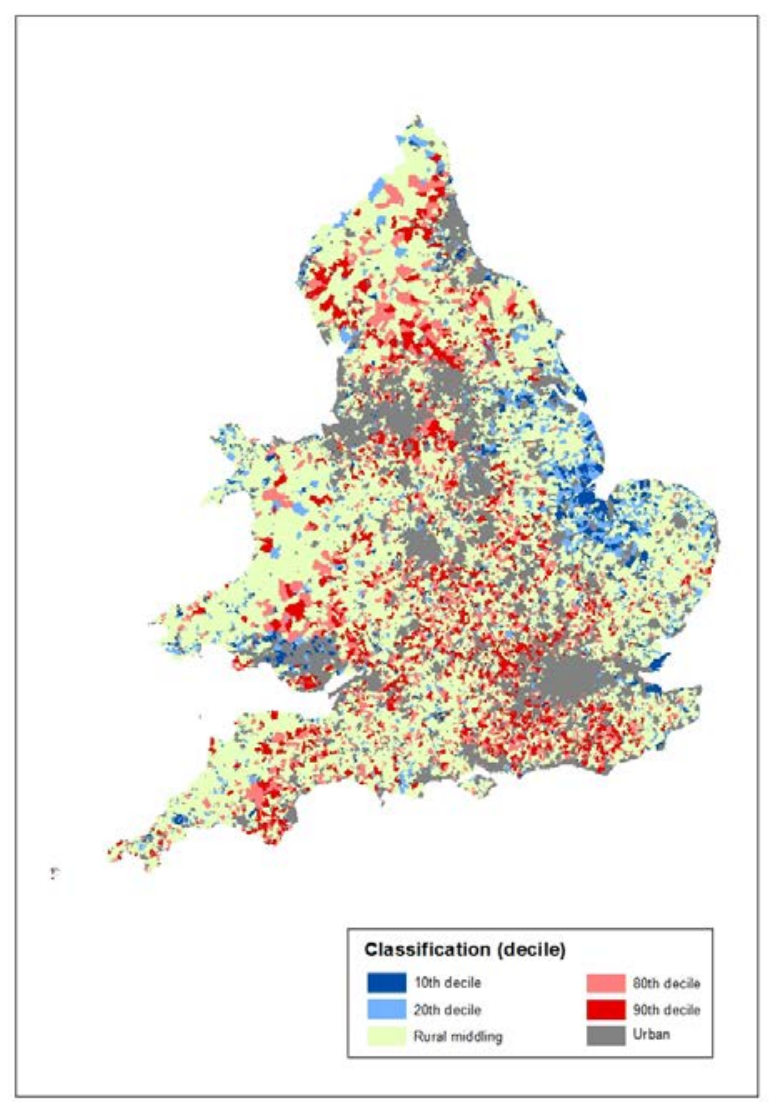

It is plausible that many of these rural locations are being dramatically changed by the exclusionary processes of gentrification, and are displacing or marginalising lower income groups to less desirable rural places. Although it may be an exaggeration of the scale and magnitude of gentrification, according to the national media during the last two decades, $70 \%$ of the British countryside is gentrified by the middle class (Financial Times, $30 / 08 / 15$ ), and 'gentrification is sweeping through the countryside, riding shotgun on the collapse of Britain's farming industry and in many places pricing locals out of the market' (Guardian, 18/04/2006: 28). In this context, recent studies have importantly drawn attention to the diversity of rural gentrification processes (Stockdale, 2010; Smith et al., 2018), and also to the different phases and magnitudes of gentrification processes in rural places with high middle class populations (e.g. Phillips 2005).

Figure 3 also reveals the relative absence (i.e. dark blue, $10^{\text {th }}$ decile [10.342.2\%]) of middle class populations in the fenland areas of Lincolnshire, 
Cambridgeshire and Norfolk, coastal and north Lincolnshire, the Solway coast and Arnside in Cumbria, Silverdale in Lancashire, the South Wales Valleys, and Goss Moor Cornwall. Perhaps conditions and connotations of entrenched socio-economic decline, coupled with perceptions of less appealing rural landscapes and cultures, might be important factors for explaining the low proportions of middle class populations.

Table 3: Regional distribution of middle class individuals by $90^{\text {th }}$ decile (2011 UK census)

\begin{tabular}{|l|r|r|r|r|r|}
\hline & Village & $\begin{array}{c}\text { Village in a } \\
\text { Sparse } \\
\text { Setting }\end{array}$ & $\begin{array}{c}\text { Hamlets and } \\
\text { Isolated } \\
\text { Dwellings }\end{array}$ & $\begin{array}{c}\text { Hamlets and } \\
\text { Isolated } \\
\text { Dwellings in } \\
\text { a Sparse } \\
\text { Setting }\end{array}$ & Total \\
\hline $\begin{array}{l}\text { East } \\
\text { Midlands }\end{array}$ & 116 & 0 & 44 & 0 & $160(9.1 \%)$ \\
\hline East & 80 & 0 & 65 & 1 & $146(8.3 \%)$ \\
\hline London & 1 & 0 & 0 & 0 & $1(0.1 \%)$ \\
\hline North East & 21 & 1 & 26 & 7 & $55(3.1 \%)$ \\
\hline North West & 62 & 1 & 102 & 14 & $179(10.1 \%)$ \\
\hline South East & 288 & 0 & 286 & 0 & $574(32.5 \%)$ \\
\hline South West & 124 & 5 & 144 & 17 & $290(16.4 \%)$ \\
\hline Wales & 34 & 7 & 26 & 18 & $85(4.8 \%)$ \\
\hline West Mids & 54 & 0 & 81 & 13 & $148(8.4 \%)$ \\
\hline Yorkshire \& & 51 & 3 & 65 & 9 & $128(7.2 \%)$ \\
\hline The Humber & & 17 & 839 & 79 & 1,766 \\
\hline Total & & & & & \\
\hline
\end{tabular}

\subsection{Working class individuals}

Reflecting the findings above, Figure 4 shows that OAs in the $90^{\text {th }}$ decile (41.4\%-69.8\%) of working class populations (NS-SEC 5, 6 and 7) are also concentrated in Goss Moor area in Cornwall (with declining china clay industries), South Wales Valleys, the Solway coast and Silverdale in Cumbria, Arnside in Lancashire, coastal, the fenland areas of Lincolnshire, Norfolk and Cambridgeshire, and coastal and north Lincolnshire. This points to a seemingly dichotomous relationship between the presence of middle class 
and absence of working class populations, and vice versa. It is possible that these social class divisions in rural England and Wales may be widening, as middle class-dominated rural places become more exclusive, via rising property prices and the increasing lack of affordable housing, and working class populations become relatively absent (i.e. the blue areas on the map showing the $10^{\text {th }}$ decile $\left[3.8 \%-15.9 \%\right.$ and $20^{\text {th }}$ decile $\left.[15.9-18.8 \%]\right)$.

\section{Figure 4: Working class rural populations (2011 UK census)}

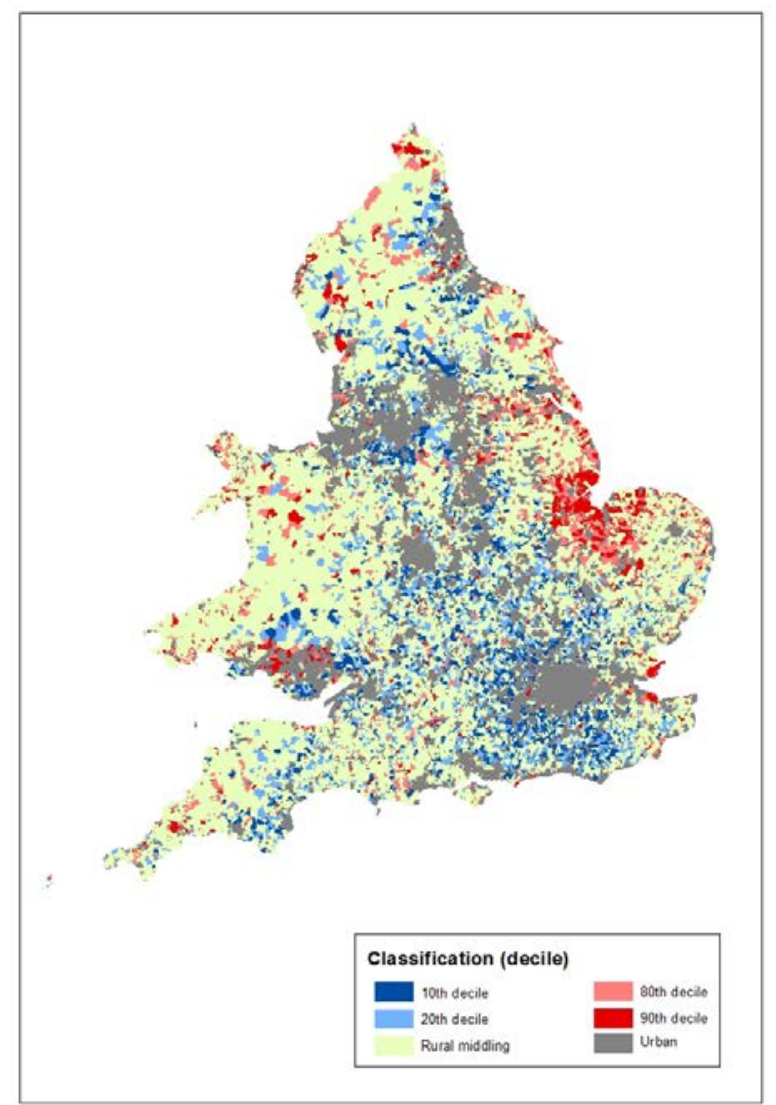

Table 4 shows that at a regional level, the $90^{\text {th }}$ decile for working class individuals is most concentrated in Wales (18.4\%), East of England (18.4\%), East Midlands (15.4\%) and South West (14.7\%), in part, exemplifying the subregional clusters of working class populations, outlined above. What is particularly striking in Table 4 is the predominance of working class individuals in villages (68.9\%), as opposed to more sparsely-populated rural areas. This may be due to more sparsely-populated areas being either gentrified (see below) or dominated by agricultural workers (see above). 
Table 4: Regional distribution of working class individuals by $90^{\text {th }}$ decile (2011 UK census)

\begin{tabular}{|c|c|c|c|c|c|}
\hline & Village & $\begin{array}{c}\text { Village in a } \\
\text { Sparse } \\
\text { Setting }\end{array}$ & $\begin{array}{c}\text { Hamlets and } \\
\text { Isolated } \\
\text { Dwellings }\end{array}$ & $\begin{array}{l}\text { Hamlets and } \\
\text { Isolated } \\
\text { Dwellings in } \\
\text { a Sparse } \\
\text { Setting }\end{array}$ & Total \\
\hline $\begin{array}{l}\text { East } \\
\text { Midlands }\end{array}$ & 188 & 13 & 62 & 9 & $272(15.4)$ \\
\hline $\begin{array}{l}\text { East of } \\
\text { England }\end{array}$ & 251 & 19 & 47 & 7 & $324(18.4)$ \\
\hline London & 1 & 0 & 0 & 0 & $1(0.1)$ \\
\hline North East & 74 & 13 & 16 & 7 & $110(6.2)$ \\
\hline North West & 59 & 24 & 14 & 5 & $102(5.8)$ \\
\hline South East & 114 & & 18 & & $132(7.5)$ \\
\hline South West & 193 & 25 & 39 & 2 & $259(14.7)$ \\
\hline Wales & 149 & 129 & 33 & 14 & 325 (18.4) \\
\hline $\begin{array}{l}\text { West } \\
\text { Midlands }\end{array}$ & 94 & 5 & 18 & 1 & $118(6.7)$ \\
\hline $\begin{array}{l}\text { Yorkshire } \\
\text { and The } \\
\text { Humber }\end{array}$ & 92 & 8 & 20 & 2 & $122(6.9)$ \\
\hline Total & 1215 & 236 & 267 & 47 & 1765 \\
\hline
\end{tabular}

\subsection{Ties between different rural populations and property prices}

The uneven rural social class geographies expressed by Figures 3 and 4, and Tables 3 and 4, are clearly reflected in Figure 5, which shows median house price change between 2001 and 2014 using land registry data (Middle Super Output Area mapped at OA). As can be seen, lowest price changes are mostly evident in the rural areas with highest proportions of working class populations, outlined above. The most marked house price changes tend to be evident in rural areas with the high middle class populations. Interestingly, proximity to metropolitan centres does not appear to be an a priori marker of higher property prices, perhaps pointing to the importance of other possible factors such as rural aesthetics, village morphology, and rural service provisions on property price differentials. 


\section{Figure 5: Median rural house price change (2001-2014, Land Registry)}

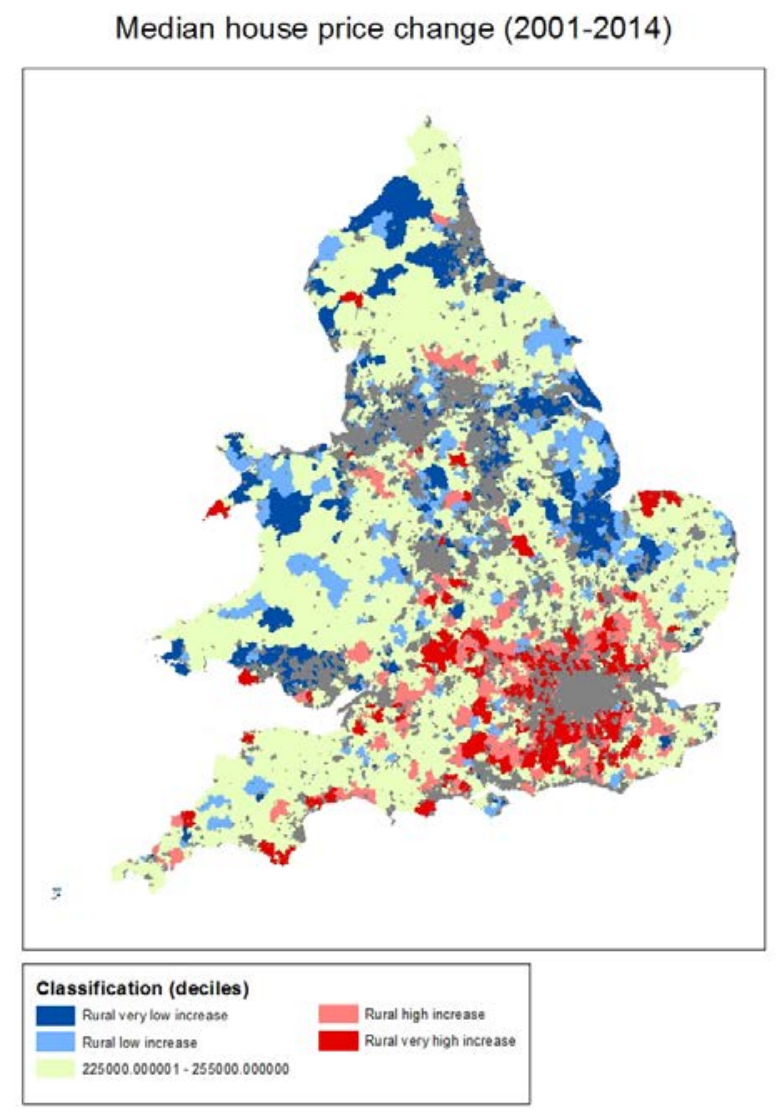

Some coastal locations appear in the $90^{\text {th }}$ decile in Figure 5, such as Dorset, south Devon, north Cornwall, and north Norfolk. This may well reflect the continuing gentrification of these prized coastal location by relatively affluent, in-migrant mature populations at pre- and post-retirement phases of their lifecourse, these areas having long been identified as sites for such migration (e.g. Clout 1972; Parsons 1980; Phillips and Williams 1984; Phillips 2005). Indeed, there is growing scholarship within both policy and academic discourses (e.g. Lowe and Speakman 2006; Davies and James, 2016; Maclaren, 2018) stressing issues of ageing within in rural locations in the UK. It is widely noted that this has serious implications for the supply and demand of public (e.g. health and social care) and private (e.g. retail and leisure) services, with wider knock-on consequences for levels of poverty and deprivation, housing affordability, local labour markets, sustainability of rural schools, and expressions of social capital/volunteering and community cohesion (Hardill, 2009). In the next section we will explore the distribution of this population in more detail. 


\subsection{Populations aged 65 or more}

Figure 6 shows the distribution of households with one of more individuals aged 65 or over, as a percentage of total households. Clearly, there are concentrations of OAs in the $90^{\text {th }}$ decile (35.1\%-90.8\%) within Snowdonia, Ceredigion, Quantock Hills, South Devon AONB, Dorset AONB, north Devon and Somerset, rural environs of Bognor Regis, Romney, Southwold, the north Norfolk coast, and coastal Lincolnshire. Away from the coastline, there are also relatively high concentrations of OAs in the $90^{\text {th }}$ decile in parts of the Lake District, Yorkshire Dales, North York Moors and south Warwickshire.

Given the character of many of these rural locations, it is likely that inmigration may be influential here in the reproduction of these rural places as locations for retirement. It is important to recognise that the relative strength of a retired population in an area might be reflective of the out-migration of younger age groups, and it also likely that there will be some important social class differentials tied to particular places. For example, Lincolnshire has seen a proliferation of 'retirement parks' (Bevan, 2010; Beatty et al., 2011), in contrast, for example, to the development of high-cost, new-build, retirement apartments in parts of Cornwall and Dorset (Leger et al., 2016).

What Figure 6 would appear to express is that representations of rural households with one or more member aged 65 or over are less salient in the rural areas (shaded blue) of the 'home counties' of Buckinghamshire, Essex, Hertfordshire, Surrey, Sussex and, to a lesser extent, Kent, and other counties in relative proximity to London, such as Berkshire and Cambridgeshire, plus Cheshire, the Trans-Pennine corridor; Wiltshire, Porth Cawl, and inland Cornwall. 
Figure 6: Households with one or more aged 65 or over (2011 UK census)

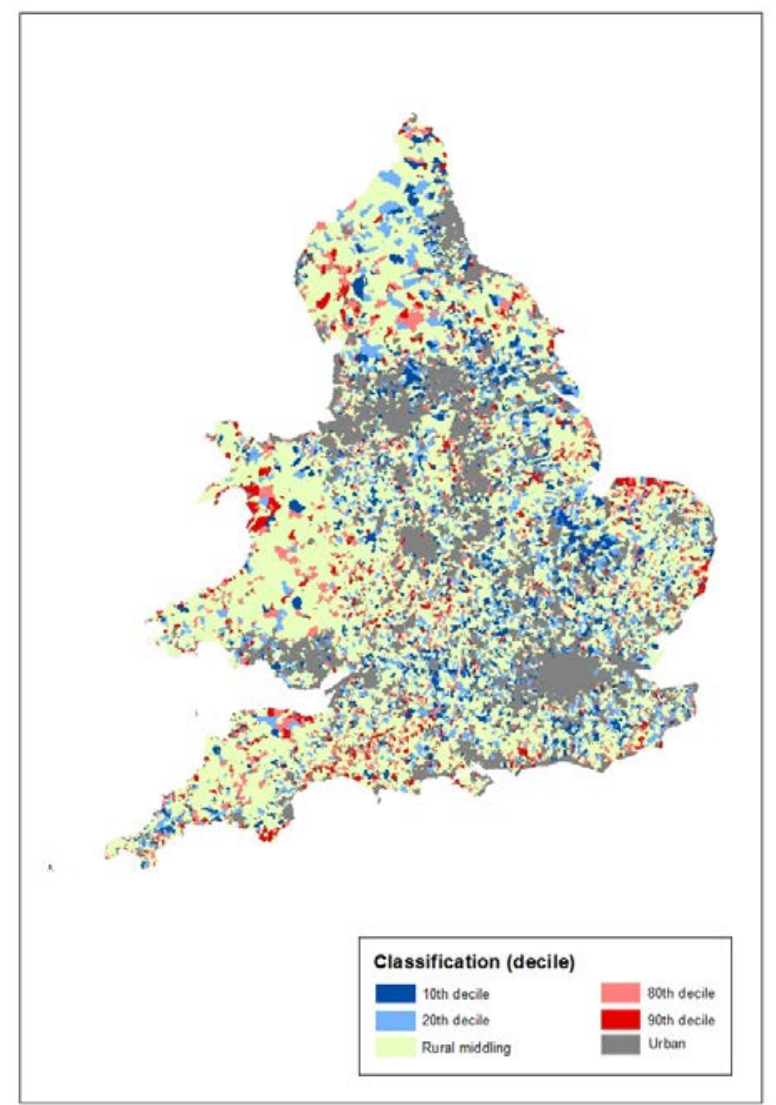

At a regional level, further analysis (Table 5) supports this characterisation, revealing that there are highest concentrations of households (90th decile) with one more adults aged 65 or over in OAs in the South West, South East and East of England (55\% of the total OAs). It also suggests that there is a preponderance of such OAs within the Villages and Hamlets and Isolated Dwellings categories (89.5\%), and a limited presence in more sparse rural locations (10.5\%). It is unsurprising that these age groups and households tend to be relatively absent from the most sparse rural locations where access to health, social care and other services is often less accessible: although there is evidence that elderly in such areas may be resistant to move despite the lack of such services (e.g Burholt, 2006), Champion and Shepherd (2006) have argued that there is also net out-migration from village and dispersed settlement areas amongst people over 75 , particularly in those categorised as sparse. 
Table 5: Regional distribution of Households with one or more aged 65 or over by $90^{\text {th }}$ decile (2011 UK census)

\begin{tabular}{|c|c|c|c|c|c|}
\hline & Village & $\begin{array}{c}\text { Village in a } \\
\text { Sparse } \\
\text { Setting }\end{array}$ & $\begin{array}{c}\text { Hamlets and } \\
\text { Isolated } \\
\text { Dwellings }\end{array}$ & $\begin{array}{l}\text { Hamlets and } \\
\text { Isolated } \\
\text { Dwellings in } \\
\text { a Sparse } \\
\text { Setting }\end{array}$ & Total \\
\hline $\begin{array}{l}\text { East } \\
\text { Midlands }\end{array}$ & 129 & 2 & 31 & 4 & $166(9.4 \%)$ \\
\hline $\begin{array}{l}\text { East of } \\
\text { England }\end{array}$ & 148 & 3 & 95 & 1 & 247 (14.0\%) \\
\hline London & 1 & & & & $1(0 \%)$ \\
\hline North East & 38 & 11 & 30 & 7 & $86(4.9 \%)$ \\
\hline North West & 61 & 14 & 56 & 13 & $144(8.1 \%)$ \\
\hline South East & 186 & & 125 & & $311(17.6 \%)$ \\
\hline South West & 210 & 24 & 145 & 34 & $413(23.4 \%)$ \\
\hline Wales & 46 & 31 & 17 & 23 & $117(6.6 \%)$ \\
\hline $\begin{array}{l}\text { West } \\
\text { Midlands }\end{array}$ & 86 & & 58 & 8 & $152(8.6 \%)$ \\
\hline $\begin{array}{l}\text { Yorkshire } \\
\text { and The } \\
\text { Humber }\end{array}$ & 73 & 7 & 45 & 4 & $129(7.3 \%)$ \\
\hline Total & 978 & 92 & 602 & 94 & 1,766 \\
\hline
\end{tabular}

\subsection{Lone Parents}

The next population group we wish to focus upon are lone parents with dependent children. As Hughes (2017) has remarked, the presence of lone parents in rural areas has been widely overlooked, in stark contrast to the attention given to this social group within urban space (e.g. Hawkes, 2017). This is important given the overall mean for lone parents with dependent children is higher for rural OAs (8.8\%), when compared to the urban OAs (7.0\%).

In the rural context, it would appear that rural OAs in the $90^{\text {th }}$ decile $(10.7 \%$ 34.5\%) are concentrated in Pembrokeshire, the South Wales Valleys, and North Wales, a distribution that might connect to the low levels of house price 
inflation in these areas (see Figure 5). Conversely, the OAs in the $10^{\text {th }}$ decile in relation to lone parent with dependent children (0-2.6\%) may be seen to lie in areas of high housing price increases such as the home counties and in areas of strong middle class presence such as the Forest of Bowland. Of course, there may be a melee of cross-cutting factors underpinning these different rural geographies of lone parenting that perhaps span different expressions of social class, economic capital and income, and cultural lifestyles, emphasising the need to transcend the stereotypes of lone parenting and social deprivation. For instance, rural residence for some middle-class, and, equally working-class, lone parents may possibly have socio-cultural meaning as 'escape areas', enabling a 'fresh start' after the breakdown and / or dissolution of a marriage or cohabiting union (Smith and Culora, 2017).

Figure 7: Lone parents with dependent children (2011 census)

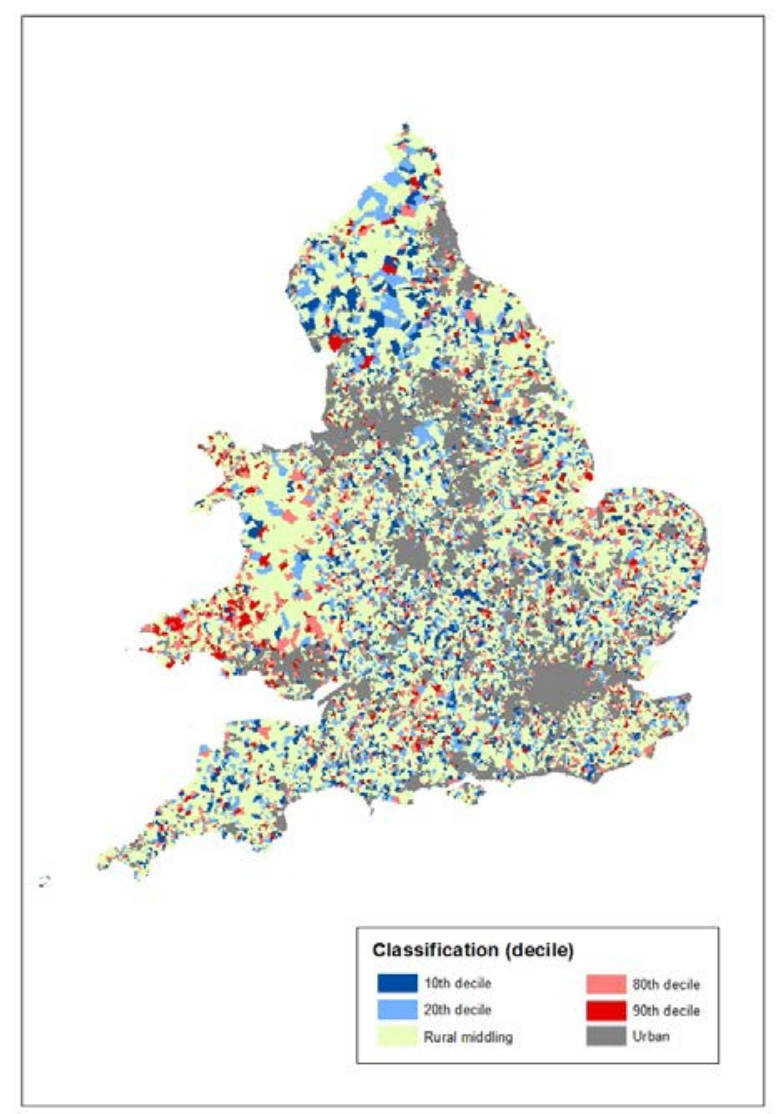


The distinct sub-regional geographies of lone parents are, in part, masked in the wider regional breakdowns of lone parents $90^{\text {th }}$ decile (see Table 6). It can be seen that the regions with highest levels of lone parents are South West (18.0\%), South East (17.1\%), East of England (16.1\%), West Midlands $(12.6 \%)$ and North West (10.0\%). This may point to the presence of lone parents across rural locations, and raise questions about linking lone parenthood with socio-economic differentiation, $\mathrm{n}^{2}$ otwithstanding the appearance of some sub-regional 'hot-spots'within in Figure 7.

Table 6: Regional distribution of lone parents with dependent child(ren) by $90^{\text {th }}$ decile (2011 UK census)

\begin{tabular}{|c|c|c|c|c|c|}
\hline & Village & $\begin{array}{l}\text { Village in a } \\
\text { Sparse } \\
\text { Setting }\end{array}$ & $\begin{array}{l}\text { Hamlets and } \\
\text { Isolated } \\
\text { Dwellings }\end{array}$ & $\begin{array}{l}\text { Hamlets and } \\
\text { Isolated } \\
\text { Dwellings in } \\
\text { a Sparse } \\
\text { Setting }\end{array}$ & Total \\
\hline $\begin{array}{l}\text { East } \\
\text { Midlands }\end{array}$ & 110 & 5 & 39 & 1 & 155 (8.8\%) \\
\hline $\begin{array}{l}\text { East of } \\
\text { England }\end{array}$ & 185 & 6 & 93 & 1 & 285 (16.1\%) \\
\hline London & 4 & & 1 & 0 & $5(0.3 \%)$ \\
\hline North East & 8 & 2 & 3 & 0 & $13(0.7 \%)$ \\
\hline North West & 85 & 11 & 69 & 11 & $176(10.0 \%)$ \\
\hline South East & 187 & & 115 & & 302 (17.1\%) \\
\hline South West & 172 & 13 & 121 & 11 & 317 (18.0\%) \\
\hline Wales & 52 & 53 & 39 & 27 & $171(9.7 \%)$ \\
\hline $\begin{array}{l}\text { West } \\
\text { Midlands }\end{array}$ & 107 & 6 & 92 & 18 & $223(12.6 \%)$ \\
\hline $\begin{array}{l}\text { Yorkshire } \\
\text { and The } \\
\text { Humber }\end{array}$ & 63 & 5 & 45 & 6 & 119 (6.7\%) \\
\hline Total & 973 & 101 & 617 & 75 & 1,766 \\
\hline
\end{tabular}

\subsection{Couples with children}

Figure 8 shows the geographical distribution of couples (married/cohabiting) with dependent or non-dependent children, as a percentage of total households. This is an important variable given idyllic representations of 
rurality often reinforce rural places as a bucolic spaces for family forming and the rearing of children, often coupled to the presence of high-performing rural schools (Smith and Higley, 2012), and the possibility of a healthy and safer family life that is closer to nature.

It can be seen that there is a distinctive ring of OAs in the $90^{\text {th }}$ decile (36.7\%85.5\%) around London, which extends northwards along the routes of the M1 (Buckinghamshire/Bedfordshire), A1 (Hertfordshire) and M11 (Essex/Cambridgeshire) road networks. Three other notable concentrations of OAs in the $90^{\text {th }}$ decile can be identified in: Cheshire/Shropshire; Forest of Bowland; Vale of York/North Yorkshire, rural environs of Cardiff, and the West/East Midlands.

Figure 8: Couple households (married/cohabiting) with dependent or non-dependent children (2011)

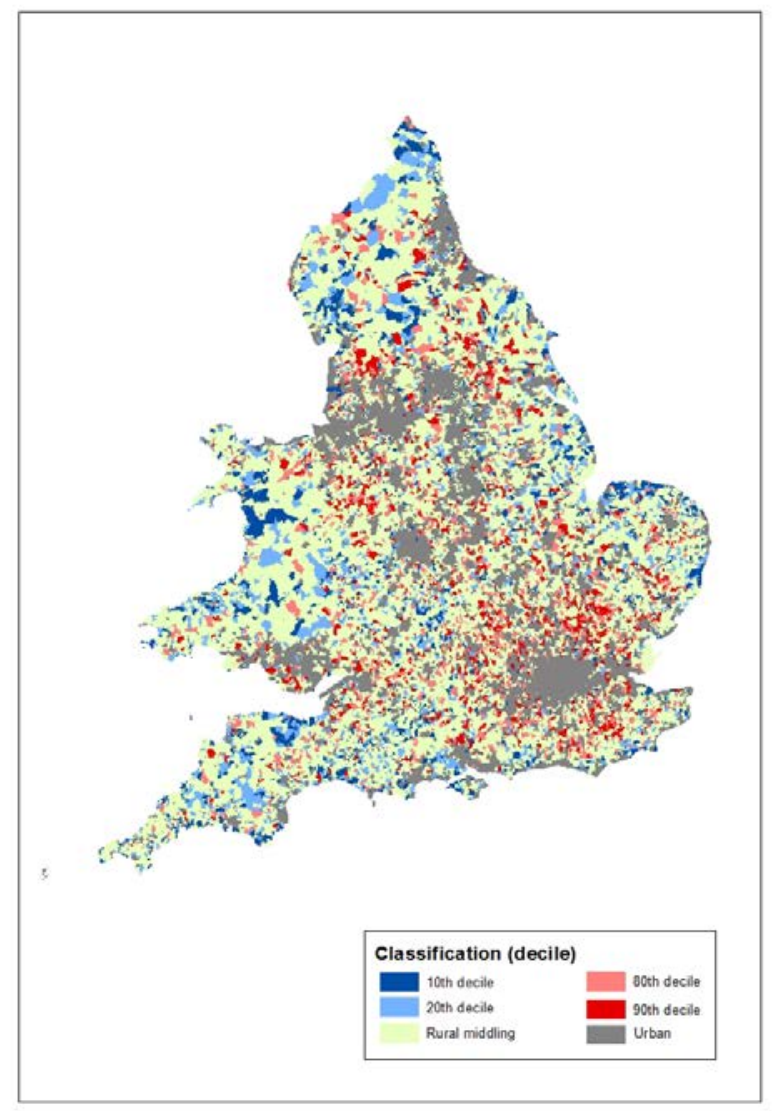

It would therefore appear that there is a relationship between large metropolitan urban centres and relatively high concentrations of couples with 
children on the rural fringes. In rural locations that are more remote from the metropolitan centres, such as Cornwall, Dorset, Ceredigion, Snowdonia, Lake District/Cumbria, Northumberland, Lincolnshire, Norfolk, South-East coastline, there are relatively low concentrations of couples with children in rural areas. This distributions begs a series of questions. First, are couples with children gravitating to rural areas in striking distance of urban metropolitan centres for employment reasons or to access cultural infrastructures in urban centres? Second, are other factors, perhaps working in combination with the above, important in attracting couples to certain rural locations, such as the provision of high performing schools (see Smith and Higley 2012)? Or, third, is the distribution of couples with children a reflection of the presence of other groups in particular areas, such as elderly households in some retirement locations. To address such issues, it is worthwhile considering the distribution of couples without children.

\subsection{Couples without children}

Figure 9 shows the geographies of childless couples (married/cohabiting) as a percentage of total households. What can be seen from Figure 9 is that OAs in the $90^{\text {th }}$ decile (30.8\%-54.4\%) tend to be generally more prevalent in the north and east of England, with the exception of the south-east of England. By contrast, OAs in the $10^{\text {th }}$ decile (1.5\%-17.2\%) are concentrated in North Wales, Pembrokeshire, North Cornwall, and the rural environs of London. Perhaps one of the factors for the low proportion of childless couples in these rural locations is the specific local and regional labour markets of North Wales, Pembrokeshire, and North Cornwall. It is possible that (young) childless couples do not tend to gravitate towards or remain in rural locations that are in relative distant from metropolitan labour markets.

Conversely, the relative absence of childless couples in the close rural environs of London may reflect the high cost of housing in these rural locations, with childless couples at pre-family forming phases of their lifecourse as yet not having amassed appropriate levels of economic capital or earning power to compete in these housing markets and/or to take in the economic burdens of raising a family, or may have a predilection for more of 
an urban-based way of living/lifestyle. Overall, Figures 7 to 9 disrupt simplistic representations of rural places based on dichotomous relationship that hinges on the presence or absence of children in rural places.

Figure 9: Couple households (married/cohabiting) without dependent or non-dependent children (2011)

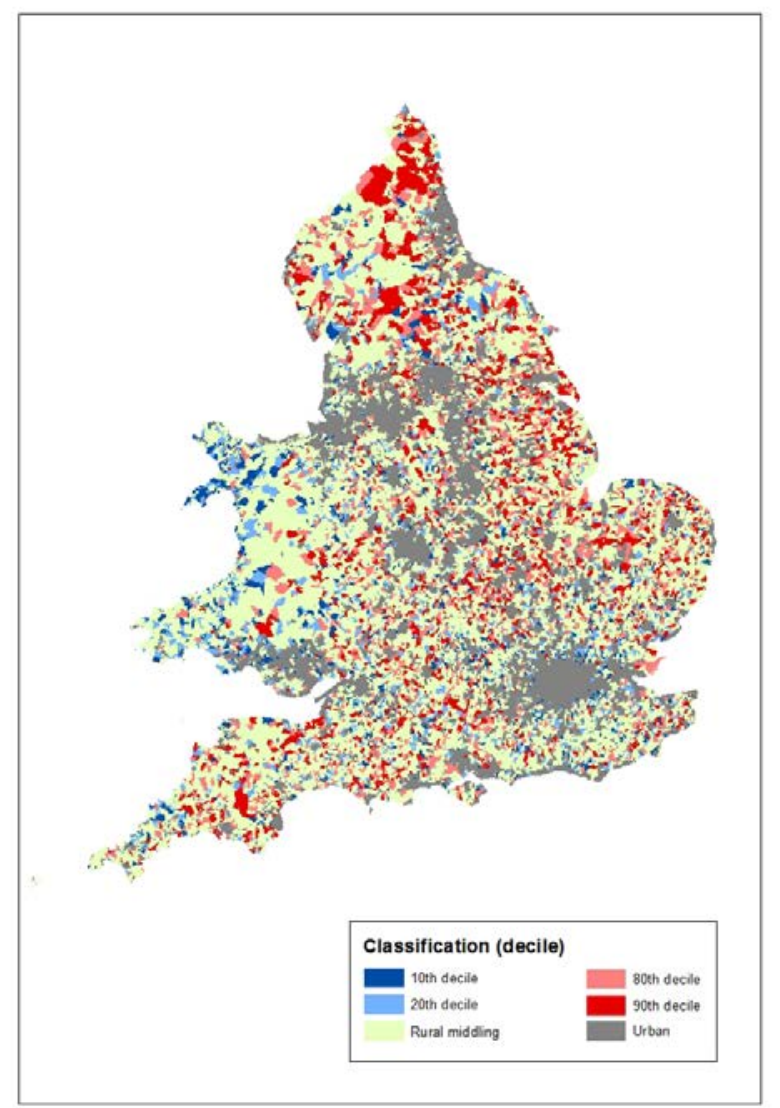

\section{Discussion and conclusion}

Our main aim in this chapter was to explore the unevenness of rural populations with a focus on some key rural population dimensions using census data. Our analysis has pointed to an increasingly differentiated countryside, whereby relatively affluent and less-affluent rural households increasingly live-apart both socially and spatially, and/or may undertake disconnected, 'parallel lives' in distinct rural spaces across England and Wales. 
It would appear that these sociospatial divisions are further complicated by lifecourse-related factors and different family formations, and possibly the predilection for different living arrangements. Crucially, we have crafted a representation of rural populations based on 2001 and 2011 Census data, which perhaps illustrates the exclusionary processes of rural change that unfolded during the 2000s, including the prominence of counterurban-led rural gentrification (see Phillips and Smith, 2018b), alongside the restructuring of agriculture under conditions of capitalist restructuring and globalisation.

In this context, what is particularly intriguing to contend is that it is possible that the pace and rate of rural population change may have slowed down during the 2000s, and that the dynamics of rural population change may not be as pronounced as the previous decade. Key here is the influence of migration on geographies of rural population change, including in-, out- and intra-migration within rural locations. For example, The State of the Countryside Report (2010) stressed: 'the slowing of in-migration to rural areas noted in 2008 has continued' (Commission for Rural Communities, 2010: 1). Likewise, there is a rapidly growing academic scholarship that provides empirical evidence to affirm the reduction of internal migration flows per se (e.g. Smith and Sage, 2014; Shuttleworth and Champion, 2017). What this may mean for rural populations is that local changes in the future may be more tied to the natural ageing processes of rural populations, as opposed to being most significantly shaped by the effects of rural in-, out- and intramigration.

However, our own analysis of 2001 and 2011 census data found that the overall mean proportion of in-migrants within rural OAs was relatively static between 2000-01 (12.9\%) and 2010-11 (12.2\%) (using the one year measure of migration). Of course, this may represent pre- and post-recession flows of rural in-migration, and may not capture the slow-down of in-migration during the economic recession years of 2007-2009. Clearly, further research is required to pin down how rural places are being reconfigured by contemporary migration processes, and how this compares to population movements into, out of and between urban counterparts. 
To conclude, it is clear from our analysis that processes of population change have yielded a more diverse set of rural geographies. The British countryside is increasingly being sub-divided, both socio-culturally and spatially, through the exclusionary workings of rural (and urban) labour, housing and education markets (Hemming and Roberts, 2018), and the ways in which both general and contingent geographic conditions can stimulate commonalities and diversities within and between rural locations warrants the urgent attention of social scientists, particularly as the outcomes will have serious policy implications for provision of health, housing, education, social care, policing, and other public and private rural services.

\section{References}

Anderson, A.R., Wallace, C. and Townsend, L., 2016. Great expectations or small country living? Enabling small rural creative businesses with ICT. Sociologia ruralis, 56(3), pp.450-468.

Beatty, C., Fothergill, S., Powell, R. and Scott, S., 2011. The Caravan Communities of the Lincolnshire Coast. Sheffield: CRESR, Sheffield Hallam University.

Bell, D. and Jayne, M., 2010. The creative countryside: Policy and practice in the UK rural cultural economy. Journal of rural studies, 26(3), pp.209-218.

Bevan, M., 2010. Retirement lifestyles in a niche housing market: park-home living in England. Ageing \& Society, 30(6), pp.965-985.

Bibby, P. and Brindley, P., 2013. The 2011 Rural-Urban Classification For Small Area Geographies: A User Guide and Frequently Asked Questions (v1. 0). UK Government Statistical Service, 28th August.

Bosworth, G. and Venhorst, V., 2017. Economic linkages between urban and rural regions-what's in it for the rural?. Regional Studies, pp.1-12. 
Burholt, V., 2006. 'Adref': theoretical contexts of attachment to place for mature and older people in rural North Wales. Environment and Planning $A$ 38, pp. $1095-1114$.

Champion, T., and Shepherd, J., 2006. Demographic chnage in rural England, in: Lowe, P., Speakman, L. (Eds.), The Ageing Countryside: the Growing Older Population of Rural England. London: Age Concern, pp. 29-50.

Champion, T. and Shuttleworth, I., 2017. Are people changing address less? An analysis of migration within England and Wales, 1971-2011, by distance of move. Population, Space and Place, 23(3).

Clark, M.A., 2018. Teleworking in the countryside: Home-based working in the information society. Routledge.

Cloke, P. and Thrift, N., 1987. Intra-class conflict in rural areas. Journal of Rural studies, 3(4), pp.321-333.

Cloke, P., Goodwin, M., 1992. Conceptualizing countryside change: from postFordism to rural structured coherence. Transactions, Institute of British Geographers 17, pp. 321-336.

Clout, H., 1972. Rural geography: an introductory survey. Pergamon, Oxford.

Commission for Rural Communities. 2010. The State of the Countryside Report (2010). Available: http://webarchive.nationalarchives.gov.uk/20110303181543/http://ruralcommu nities.gov.uk/files/sotc/sotc2010.pdf

Davies, A. and James, A., 2016. Geographies of ageing: Social processes and the spatial unevenness of population ageing. Routledge.

Hardill, I. 2009. Introduction: Geographies of aging, The Professional 
Geographer 61: 1-3.

Gkartzios, M. and Scott, M., 2010. Residential mobilities and house building in rural Ireland: evidence from three case studies. Sociologia Ruralis, 50(1), pp.64-84.

Goodwin-Hawkins, B., 2015. Mobilities and the English village: moving beyond fixity in rural West Yorkshire. Sociologia ruralis, 55(2), pp.167-181.

Halfacree, K., 2014. Jumping up from the armchair: beyond the idyll in counterurbanisation. In Understanding Lifestyle Migration (pp. 92-115). Palgrave Macmillan, London.

Halfacree, K., 2018. From Ambridge to the world? Class returns to rural population geographies. Dialogues in Human Geography, 8(1), pp.26-30.

Hawkes, D., 2017. Child health and lone motherhood: evidence from the UK Millennium Cohort Study. In Fertility, Health and Lone Parenting (pp. 88-100). Routledge.

Heley, J., 2010. The new squirearchy and emergent cultures of the new middle classes in rural areas. Journal of Rural Studies, 26(4), pp.321-331.

Hemming, P.J. and Roberts, C., 2018. Church schools, educational markets and the rural idyll. British Journal of Sociology of Education, 39(4), pp.501517.

Hennessy, C.H., Means, R. and Burholt, V. eds., 2014. Countryside connections: Older people, community and place in rural Britain. Policy Press.

Hoggart, K., 1997. The middle classes in rural England, 1971-1991. Journal of Rural Studies 13, pp. 253-273. 
Hoggart, K., 2007. The diluted working classes of rural England and Wales. Journal of Rural Studies 23, pp. 305-317.

Holloway, L. and Hubbard, P., 2014. People and place: The extraordinary geographies of everyday life. Routledge.

Hughes, A., 2017. Geographies of invisibility: the 'hidden'lives of rural lone parents. In Geographies of rural cultures and societies (pp. 126-144).

Routledge.

Kasimis C., Papadopoulos A.G., Zografakis S. 2015. The precarious status of migrant labour in Greece: evidence from rural areas. In: della Porta D., Hänninen S., Siisiäinen M. and Silvasti T. (eds) The New Social Division. Palgrave Studies in European Political Sociology. Palgrave Macmillan, London

Laoire, C.N. and Stockdale, A., 2016. Migration and the life course in rural settings. Routledge International Handbook of Rural Studies, p.36.

Leger, C., Balch, C. and Essex, S., 2016. Understanding the planning challenges of brownfield development in coastal urban areas of England. Planning Practice \& Research, 31(2), pp.119-131.

Lever, J. and Milbourne, P. (2017) The structural invisibility of outsiders: the role of migrant labour in the meat-processing industry Sociology 51(2) pp. 306-322

Lowe, P., Marsden, T., Murdoch, J. and Ward, N., 2005. The differentiated countryside. Routledge.

Lowe, P., Speakman, L., (eds.) 2006. The Ageing Countryside: the Growing Older Population of Rural England. London: Age Concern. 
Maclaren, A.S., 2018. Affective lives of rural ageing. Sociologia Ruralis, 58(1), pp.213-234.

McKee, K. Hoolachan, J.E. and Moore, T. 2017. The precarity of young people's housing experiences in a rural context, Scottish Geographical Journal, 133 (2), pp. 115-129

Milbourne, P. and Kitchen, L., 2014. Rural mobilities: Connecting movement and fixity in rural places. Journal of Rural Studies, 34, pp.326-336.

Murdoch, J. and Marsden, T., 1994. Reconstituting Rurality: Class, power and community in the development process.

Nelson, L., Nelson, P.B., 2010. The global rural: gentrification and linked migration in the rural USA. Progress in Human Geography, 35, pp. 441-459.

Newby, H., 1980. Green and pleasant land? Social change in rural England. Penguin Books Ltd..

Pahl, R.E., 1965. Urbs in rure. London School of Economics Geographical Paper, (2).

Parsons, D., 1980. Rural gentrification: the influence of rural settlement planning policies. Department of Geography, University of Sussex, Brighton.

Philip, L., Macleod, M., Stockdale, A., 2013. Retirement transition, migration and remote rural communities: evidence from the Isle of Bute. Scottish Geographical Journal 129, pp. 122-136.

Philip, L.J. and MacLeod, M., 2018. Tales from a Small Island: Applying the 'Path-Dependency'Thesis to Explore Migration to a Remote Rural Community. Sociologia Ruralis, 58(1), pp.147-170. 
Phillips, D., Williams, A., 1984. Rural Britain: a Social Geography. Oxford: Basil Blackwell.

Phillips, M., 1999. Gender relations and identities in the colonisation of rural 'Middle England', in: Boyle, P., Halfacree, K. (Eds.), Gender and Migration in Britain. London: Routledge, pp. 196-214

Phillips, M., 2005. Differential productions of rural gentrification: illustrations from North and South Norfolk. Geoforum, 36(4), pp.477-494.

Phillips, M., 2010. Counterurbanisation and rural gentrification: an exploration of the terms. Population, Space and Place, 16(6), pp.539-558.

Phillips, M., 2016. Assets and affect in the study of social capital in rural communities. Sociologia ruralis, 56(2), pp.220-247.

Phillips, M. and Smith, D.P., 2018a. Comparative approaches to gentrification: Lessons from the rural. Dialogues in Human Geography, 8(1), pp.3-25.

Phillips, M. and Smith, D.P., 2018b. Comparative ruralism and 'opening new windows' on gentrification. Dialogues in Human Geography, 8(1), pp. 51-58.

Roberts, E. and Townsend, L., 2016. The contribution of the creative economy to the resilience of rural communities: exploring cultural and digital capital. Sociologia Ruralis, 56(2), pp.197-219.

Robinson, G., 2014. Geographies of agriculture: globalisation, restructuring and sustainability. Routledge.

Scott, M., Murphy, E. and Gkartzios, M., 2017. Placing 'Home' and 'Family' in Rural Residential Mobilities. Sociologia Ruralis, 57(S1), pp.598-621.

Shortall, S., 2015. Gender mainstreaming and the common agricultural policy. Gender, Place \& Culture, 22(5), pp.717-730. 
Shucksmith, M. and Brown, D.L., 2016. Framing rural studies in the global north. International handbook of rural studies, pp.1-26.

Smith, D.P. 2007. The changing faces of rural populations: "(re)fixing the gaze' or 'eyes wide shut'? Journal of Rural Studies 23(3): 275-282

Smith, D.P. and Phillips, D.A. 2001. Socio-cultural representations of greentrified Pennine rurality. Journal of Rural Studies 17(4): 457-69.

Smith, D.P. and Holt, L., 2005. 'Lesbian migrants in the gentrified valley' and 'other' geographies of rural gentrification. Journal of rural studies, 21(3), pp.313-322.

Smith, D.P. and Higley, R., 2012. Circuits of education, rural gentrification, and family migration from the global city. Journal of Rural Studies, 28(1), pp.49-55.

Smith, D.P. \& Sage, J. (2014) The regional migration of young adults in England and Wales (2002-2008): A 'conveyor-belt' of population redistribution?, Children's Geographies, 12(1): 102-117.

Smith, D.P. and Culora, A. 2017. Uneven family geographies in England and Wales: (Non)traditionality and change between 2001 and 2011. in Stillwell, J. A Handbook for Census Resources, Methods and Applications: Unlocking the UK 2011 Census. Ashgate, Chapter 18.

Smith, D.P., Phillips, M. and Kinton, C. 2018. Wilderness gentrification: 'moving off the beaten rural track'. in Lees, L. and Phillips, M. International Handbook of Gentrification. Chapter 22, p.363.

Stockdale, A., 2010. The diverse geographies of rural gentrification in Scotland. Journal of Rural Studies, 26(1), pp.31-40. 
Stockdale, A., 2014. Unravelling the migration decision-making process: English early retirees moving to rural mid-Wales. Journal of Rural Studies, 34, pp.161-171.

Stockdale, A., 2016. Contemporary and 'messy' rural in-migration processes: Comparing counterurban and lateral rural migration. Population, space and place, 22(6), pp.599-616.

Sutherland, L.A., 2012. Return of the gentleman farmer?: Conceptualising gentrification in UK agriculture. Journal of Rural Studies, 28(4), pp.568-576.

The Guardian. 2006. Gentrification, 18 April.

The Times. 2015. Middle class gentrifies 70\% of our villages. 30 August. Available: https://www.thetimes.co.uk/article/middle-class-gentrifies-70-of-ourvillages-kdl6h0ptgmm

Tyrrell, N. and Harmer, N., 2015. A good move? Young people's comparisons of rural and urban living in Britain. Childhood, 22(4), pp.551-565.

Woods, M., 2004. Rural geography: Processes, responses and experiences in rural restructuring. Sage: London.

Woods, M., 2010. Rural. Routledge: London. 
1 See www.i-rgent for more details of the project. The UK element of this project was supported by the Economic and Social Research Council [grant number ES/L016702/1].

2 One issue to bear in mind when interpreting OA based maps is that apparent hotspots might simply reflect the presence of larger scale OAs in spatial extent. 